\title{
Pengaruh Kinerja Keuangan Terhadap Nilai Perusahaan Dengan Kebijakan Dividen Sebagai Variabel Moderating
}

\author{
Rutin ${ }^{1}$, Triyonowati 2 , Djawoto ${ }^{3}$ \\ ${ }_{1,2,3}$ STIESIA Surabaya, Indonesia
}

\section{JEL Classification : \\ M41 \\ 016}

\section{Keywords :}

Company Value, Liquidity

Leverage, Activity, Profitability, Dividend Policy

\section{INFO ARTIKEL}

\begin{abstract}
Company value is generally applied to measurea company's management for further successful operations. This study aimed to investigate the effect of liquidity $(C R)$, leverage (DER), activity (TATO), profitability (ROA) and dividend policy (DPR) on the company value (PBV). Therefore, this study observed 66 manufacturing companies as samples that were obtained through purposive sampling. The data was analyzed using classic assumption test Moderated Regression Analysis (MRA) assisted with SPSS 20 for windows. As the result, this study indicated that the liquidity and activity had no significant effect on firm value; however, the leverage and profitability had a significant effect on the manufacturing company values in the period of 2013 to 2017. In addition, the dividend policy moderated the effect of liquidity and profitability on firm value; but the dividend policy could not moderate the influence of leverage and activity to the value of manufacturing companies in the period of 2013 to 2017.
\end{abstract}

\begin{abstract}
ABSTRAK
Nilai perusahaan dijadikan sebagai suatu ukuran keberhasilan manajemen perusahaan dalam prospek operasi di masa mendatang. Tujuan penelitian ini yaitu untuk mengetahui signifikansi pengaruh Likuiditas (CR), Leverage (DER), Aktivitas (TATO), Profitabilitas (ROA) dan Kebijakan Dividen (DPR) terhadap Nilai Perusahaan (PBV). Teknik penentuan sampel yang digunakan adalah purposive sampling, sebanyak 66 perusahaan Manufaktur yang menjadi sampel penelitian. Teknik analisa data yang digunakan adalah uji asumsi klasik dan Moderated Regression Analisys (MRA) dengan bantuan SPSS 20 for windows. Hasil penelitian menunjukkan Likuiditas dan Aktivitas berpengaruh tidak signifikan terhadap nilai perusahaan, sedangkan Leverage dan Profitabilitas berpengaruh signifikan terhadap Nilai Perusahaan Manufaktur periode 20132017. Kebijakan Dividen memoderasi pengaruh Likuiditas dan profitabilitas terhadap nilai perusahaan, sedangkan Kebijakan Dividen tidak mampu memoderasi pengaruh Leverage dan Aktivitas terhadap Nilai Perusahaan Manufaktur periode 20132017.
\end{abstract}

\section{Pendahuluan}

Berdirinya sebuah perusahaan harus adalah untuk mencapai keuntungan maksimal. memiliki tujuan yang jelas. Tujuan pertama 
Rutin, Triyonowati, Djawoto : Pengaruh Kinerja Keuangan Terhadap Nilai Perusahaan Dengan Kebijakan Dividen Sebagai Variabel Moderating

pemilik perusahaan atau para pemilik saham.

Dan tujuan ketiga adalah memaksimalkan 
nilai perusahaan yang tercermin pada harga sahamnya. Sartono (2010:9), menyatakan bahwa suatu nilai perusahaan dapat diartikan sebagai harga yang bersedia dibayar oleh investor seandainya suatu saham perusahaan akan dijual. Dimana nilai perusahaan dapat memberikan kemakmuran pemegang saham secara maksimum apabila harga saham meningkat. Semakin tinggi harga saham sebuah perusahaan, maka semakin tinggi pula tingkat kemakmuran pemegang saham. Suatu harga pasar saham merupakan cerminan dari nilai perusahaan.

Salah satu aspek yang dinilai investor dalam investasinya adalah kinerja keuangan. Pada prinsipnya, semakin baik kinerja keuangan perusahaan maka permintaan saham perusahaan tersebut akan meningkat, sehingga akan meningkatkan pula harga saham perusahaan. Prediksi untuk mengetahui naik turunya harga saham dikarenakan pengaruh dari kinerja keuangan perusahaan tersebut. Setiap investor yang rasional tentunya akan melakukan analisis sebelum membuat keputusan untuk membeli, menahan atau menjual saham.

Naik turunnya harga saham dipasar saham menjadi fenomena yang menarik untuk dibicarakan. Harga saham pada perusahaan manufaktur ada yang mengalami kenaikan dan ada juga yang mengalami penurunan dipasar bursa periode 2013-2017. Berdasarkan harga saham perusahaan Manufaktur yang diperoleh dari situs Bursa Efek Indonesia. Berikut ini menampilkan tabel dan grafik ratarata harga saham perusahaan Manufaktur periode 2013-2017.

Tabel 1

Rata-rata Harga Saham Perusahaan Manufaktur Periode 2013-2017

\begin{tabular}{ccc}
\hline No. & Tahun & Harga Saham \\
\hline \hline 1 & 2013 & 17,136 \\
2 & 2014 & 9,379 \\
3 & 2015 & 5,678 \\
4 & 2016 & 5,464 \\
5 & 2017 & 5,898 \\
\hline
\end{tabular}

Sumber : $\underline{w w w . i d x . c o m}$ dan harga saham dunia-investasi.

Salah satu analisa yang dapat digunakan para investor adalah analisis fundamental. Analisis ini mengacu kepada informasi yang diperoleh melalui laporan keuangan. Informasi dalam laporan keuangan juga merupakan informasi yang penting dalam melibatkan bagaimana kinerja perusahaan dan harga sahamnya dipasar.

Riyanto (2010:330), menyatakan penggunaan informasi yang disediakan sebuah perusahaan biasanya analis atau investor akan menghitung rasio-rasio keuangannya yang mencakup rasio likuiditas, leverage, aktivitas dan profitabilitas perusahaan untuk dasar pertimbangan dalam keputusan investasi. Maka dalam penelitian ini, peneliti menggunakan rasio likuiditas, leverage, aktivitas dan profitabilitas. Penelitian oleh Kurniasari (2017), mengenai pengaruh profitabilitas, aktivitas dan leverage terhadap nilai perusahaan menyimpulkan bahwa profitabilitas, aktivitas dan leverage berpengaruh terhadap nilai perusahaan.

Selain beberapa faktor diatas yang menjadi signal bagi investor dalam menilai baik buruknya suatu perusahan adalah kebijakan dividen. Dengan kata lain suatu nilai perusahaan dapat dilihat dari kemampuan perusahaan dalam membayarkan dividen. Hanafi (2014:361) menyatakan bahwa "dividen merupakan kompensasi yang diterima oleh pemegang saham, disamping capital gain". Kebijakan dividen dalam penelitian ini dijadikan sebagai variabel 
pemoderasi karena kebijakan dividen menjadi pusat perhatian banyak pihak, diantaranya oleh pemegang saham, kreditor, maupun pihak eksternal lainnya yang memiliki kepentingan dari informasi yang dikeluarkan oleh perusahaan.

Sehingga tujuan penelitian ini ialah menguji pengaruh likuiditas, leverage, aktivitas dan profitabilitas terhadap nilai perusahaan dengan kebijakan dividen sebagai kebijakan moderating.

\section{Telaah Teori Dan Pengembangan Hipotesis}

\section{Nilai Perusahaan}

Nilai perusahaan diartikan sebagai harga yang bersedia dibayar oleh investor seandainya suatu perusahaan akan dijual (Sartono, 2010:9). Nilai perusahaan dapat diartikan mencerminkan nilai aset yang dimiliki perusahaan seperti surat-surat berharga. Saham merupakan salah satu surat berharga yang dikeluarkan oleh perusahan, tinggi rendahnya harga saham banyak dipengaruhi oleh kondisi suatu emiten.

Nilai perusahaan dapat diukur dengan harga saham menggunakan rasio yang disebut rasio penilaian. Menurut Sudana (2011:23), rasio penilaian adalah suatu rasio yang terkait dengan penilaian kinerja saham perusahaan yang telah diperdagangkan di pasar modal ( $g o$ public). Rasio penilaian memberikan informasi seberapa besar masyarakat menghargai perusahaan, sehingga masyarakat tertarik untuk membeli saham dengan harga yang lebih tinggi dibanding nilai bukunya. Berikut ini beberapa metode yang digunakan untuk mengukur nilai perusahaan, yakni sebagai berikut

1. Price Earning Ratio (PER)

Menurut Reeve et al., (2010:336),

Pengertian price earning ratio adalah rasio yang merupakan indikator bagi prospek pendapatan perusahaan di masa yang akan datang dihitung dengan cara membagi harga pasar per lembar saham biasa pada tanggal tertentu dengan laba per saham tahunan.

2. Price to Book Value (PBV)

Menurut Brigham dan Houston (2010:151), rasio ini mengukur nilai yang diberikan pasar keuangan kepada manajemen dan organisasi perusahaan sebagai sebuah perusahaan yang terus tumbuh.

3. Tobin's $Q$

Menurut Smithers dan Wigrt dalam Prasetyorini (2013) menyatakan bahwa Tobin's $Q$ dihitung dengan rasio nilai pasar saham perusahaan ditambah dengan hutang kemudian membandingkan dengan total aset perusahaan.

Dalam penelitian ini, metode yang digunakan untuk mengukur nilai perusahaan adalah :

a. Price to Book Value (PBV)

Price to book value (PBV) merupakan salah satu indikator dalam menilai perusahaan. PBV mengambarkan seberapa besar pasar menghargai nilai buku saham suatu perusahaan. PBV merupakan perbandingan dari harga suatu saham dengan nilai buku. Dimana PBV sangat erat kaitannya dengan harga saham. Perubahan harga saham akan merubah rasio PBV. Rasio PBV yang semakin tinggi mengindikasikan harga saham yang semakin tinggi pula. Harga saham yang tinggi mencerminkan nilai perusahaan yang tinggi. Menurut Murhadi (2013: 66) secara matematis PBV dapat dirumuskan sebagai berikut :

$$
\text { PBV }=\frac{\text { Harga Pasar Per Lembar Saham }}{\text { Nilai Buku Saham }}
$$

\section{Analisis Rasio Keuangan}

Menganalisis suatu rasio keuangan berarti menggali lebih banyak informasi yang terkandung didalam laporan keuangan suatu perusahaan, dengan menganalisis rasio keuangan kita sudah bisa mengetahui keadaan dan hasil suatu perusahaan tanpa melihat langsung ke perusahaan tersebut. Analisis rasio keuangan dapat dilakukan dengan menganalisis laporan keuangan yang dimiliki dalam satu periode dan beberapa periode tergantung dari tujuan dan kebutuhan.

\section{Kinerja Keuangan}

Menurut Munawir (2010:30), kinerja keuangan perusahaan merupakan satu diantara dasar penilaian mengenai kondisi keuangan perusahaan yang dilakukan berdasarkan analisa terhadap rasio keuangan perusahaan. 
Penilaian ini dilakukan dengan membandingkan rasio keuangan yang diperoleh dengan standar rasio keuangan yang ada. Dengan membandingkan rasio keuangan pada beberapa tahun penilaian dapat dilihat bagaimana kemajuan ataupun kemunduran kinerja keuangan sesuai dengan kegunaan masing-masing rasio tersebut.

Laporan keuangan suatu perusahaan dianggap penting karena digunakan sebagai dasar dalam pengambilan keputusan. Menurut Hanafi dan Halim (2009:49), menyatakan bahwa laporan keuangan perusahaan merupakam sumber informasi yang penting disamping informasi yang lainnya, seperti informasi industri, kondisi perekonomian, pangsa pasar perusahaan, kualitas manajemen dan lainnya.

\section{Rasio Keuangan}

Menurut Kasmir (2016:93), rasio keuangan adalah kegiatan membandingkan angka-angka yang ada dalam laporan keuangan dengan cara membagi satu angka dengan angka lainnya. Hasil dari rasio keuangan nantinya akan digunakan untuk menilai kinerja manajemen dalam suatu periode. Disamping itu digunakan juga untuk menilai kemampuan manajemen dalam memberdayakan sumber daya perusahaan (aset) secara efektif dan efisien.

\section{Likuiditas}

Menurut Kasmir (2016:110), Rasio likuiditas merupakan rasio yang menunjukkan kemampuan perusahaan untuk membayar hutang jangka pendek yang jatuh tempo atau rasio yang digunakan untuk mengetahui kemampuan perusahaan dalam membiayai dan memenuhi kewajiban saat ditagih. Rasio likuiditas yang digunakan oleh peneliti dalam penelitian ini adalah :

$$
\text { Current Ratio }=\frac{\text { Aktiva Lancar }}{\text { Hutang Lancar }}
$$

\section{Leverage}

Menurut Periansya (2015:39), Rasio Leverage (rasio utang) adalah rasio yang digunakan untuk mengukur seberapa jauh aset perusahaan dibiayai dengan hutang atau dibiayai oleh pihak luar. Rasio leverage yang digunakan oleh peneliti dalam penelitian ini adalah :

$$
\text { Debt to Equity Ratio }=\frac{\text { Total Hutang }}{\text { Total Ekuitas }}
$$

\section{Aktifitas}

Menurut Kasmir (2016:114), "rasio aktivitas digunakan untuk menggetahui penggunaan semua aktiva perusahaan dibandingkan dengan penjualan dalam suatu periode tertentu. Rasio aktivitas yang digunakan oleh peneliti dalam penelitian ini adalah :

$$
\text { Total Assets Turnover }=\frac{\text { Penjualan }}{\text { Total Aktiva }}
$$

\section{Profitabilitas}

Rasio profitabilitas yakni rasio yang menilai kemampuan perusahaan dalam mencari keuntungan. Rasio ini dapat juga memberikan ukuran tingkat efektivitas manajemen suatu perusahaan. Rasio profitabilitas yang digunakan oleh peneliti dalam penelitian ini adalah :

$$
\text { Return On Assets }=\frac{\text { EBIT }}{\text { Total Aktiva }}
$$

\section{Kebijakan Dividen}

Menurut Sartono (2010:282), Kebijakan dividen adalah kesempatan investasi yang tersedia, ketersediaan dan biaya modal alternatif, dan preferensi pemegang saham untuk menerima pendapatan saat ini atau menerimanya di masa datang. Dalam penelitian ini, kebijakan dividen yang digunakan oleh peneliti adalah :

$$
\text { Return On Assets }=\frac{\text { EBIT }}{\text { Total Aktiva }}
$$

\section{Kerangka Konseptual}




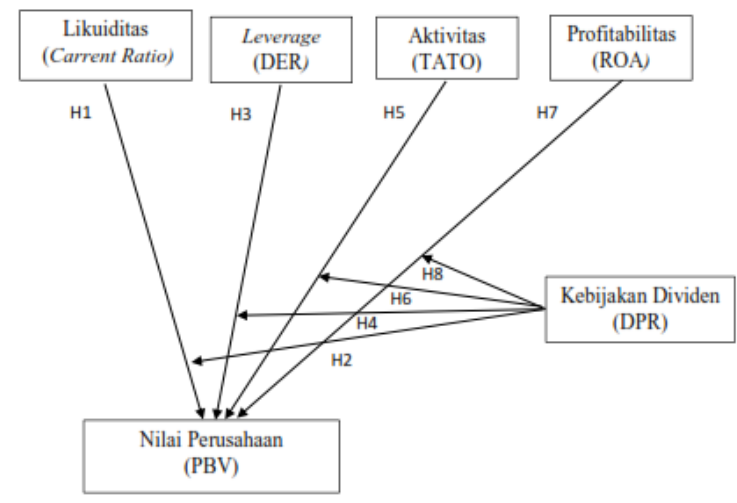

Gambar 1

Kerangka Konseptual

\section{Pengaruh Likuiditas Terhadap Nilai Perusahaan}

Likuiditas perusahaan dianggap baik apabila perusahaan mampu memenuhi kewajiban jangka pendeknya tepat waktu karena banyak dana yang tersedia bagi perusahaan untuk membiayai kegiatan operasional perusahaan dan investasinya. Perusahaan yang likuid cenderung menggunakan dana internal dalam kegiatan pendanaannya (Sartono, 2010:225).

Informasi tersebut memberikan sinyal positif bagi investor, dimana investor tertarik membeli saham diperusahaan tersebut sehingga permintaan saham meningkat yang berdampak pada meningkatnya harga saham. Harga saham yang tinggi merupakan cerminan nilai perusahaan yang tinggi. Jadi, semakin tinggi likuiditas nilai perusahaan akan meningkat.

Penelitian oleh Fadhli (2015), Anzlina dan Rustam (2013) yang mengatakan bahwa likuiditas berpengaruh terhadap nilai perusahaan. Sedangkan hasil penelitian yang tidak sesuai adalah penelitian oleh Nugroho (2012) dan Mahendra et al., (2012) yang menyatakan bahwa likuiditas tidak berpengaruh terhadap nilai perusahaan.

$\mathrm{H}_{1}$ : Likuiditas berpengaruh terhadap nilai perusahaan.

\section{Pengaruh Likuiditas Terhadap Nilai Perusahaan Dengan Kebijakan Dividen Sebagai Variabel Moderating}

Likuiditas bergantung pada arus kas perusahaan dan komponen aktiva lancar lainnya serta kewajiban lancarnya. Likuiditas perusahaan dianggap baik apabila perusahaan mampu merealisasikan non kas menjadi kas dengan memaksimumkan perputaran persediaan dan perputaran piutang perusahaan Artinya, perusahaan tersebut mempunyai dana yang lebih untuk memenuhi kewajiban jangka pendeknya tepat waktu. Informasi tersebut akan memicu investor untuk meningkatkan permintaan saham dan kemudian akan meningkatkan harga saham. Harga saham yang tinggi merupakan cerminan dari nilai perusahaan yang tinggi.

Pengaruh tersebut semakin diperkuat dengan adanya kebijakan dividen. Pembayaran dividen merupakan aliran kas keluar dan merupakan kewajiban jangka pendek perusahaan kepada pemegang saham. Berdasarkan signaling theory dalam Brigham dan Houston (2010:26) berpendapat bahwa suatu kenaikan dividen yang di atas kenaikan normal biasanya merupakan suatu sinyal kepada para investor bahwa manajemen perusahaan meramalkan suatu penghasilan yang baik dimasa yang akan datang. Dan sebaliknya.

Penelitian oleh Mery (2017), Lestari (2017), Fadhli (2015) serta penelitian oleh Sundari dan Utami (2013) yang mengatakan bahwa kebijakan dividen memoderasi pengaruh likuiditas terhadap nilai perusahaan. Sedangkan penelitian oleh Adibah (2015) dan Mahendra et al., (2012) menyatakan bahwa kebijakan dividen tidak memoderasi pengaruh likuiditas terhadap nilai perusahaan.

$\mathrm{H}_{2}$ : Kebijakan dividen memoderasi pengaruh likuiditas terhadap nilai perusahaan.

\section{Pengaruh Leverage terhadap Nilai Perusahaan}

Berdasarkan teori signaling dalam Hanafi (2014:371), peningkatan rasio hutang perusahaan memberikan sinyal positif bagi para investor dengan asumsi bahwa aliran kas perusahaan dimasa yang akan datang akan terjaga dan adanya hutang juga menunjukkan optimisme dari manajemen dalam melakukan investasi sehingga diharapkan bahwa prospek 
perusahaan di masa yang akan datang akan cerah. Manager bisa menggunakan hutang lebih banyak sebagai signal yang lebih credible, namun perusahaan harus tetap menyeimbangkan beberapa hutang yang layak diambil dan dari mana sumber-sumber yang dapat dipakai dalam membayar hutang agar tidak masuk dalam kategori extreme leverage (utang ekstrim).

Penelitian oleh Lestari (2017), Sutama dan Lisa (2016), Mabruroh et al., (2015), Adibah (2015) serta penelitian Nugroho (2012) yang mengatakan bahwa leverage berpengaruh terhadap nilai perusahaan. Berbeda dengan hasil penelitian oleh Anzlina dan Rustam (2017), yang menyatakan bahwa leverage tidak berpengaruh terhadap nilai perusahaan.

\section{$\mathrm{H}_{3}$ : Leverage berpengaruh terhadap nilai perusahaan.}

\section{Pengaruh Leverage Terhadap Nilai Perusahaan Dengan Kebijakan Dividen Sebagai Variabel Moderating \\ Berdasarkan signaling theory dalam} Hanafi (2014:371), penambahan hutang akan menjadi prospek yang baik dimasa yang akan datang sehingga akan memberikan sinyal positif bagi investor dengan asumsi bahwa aliran kas dimasa yang akan datang tetap terjaga. Hal ini akan meningkatkan permintaan saham oleh investor sehingga akan meningkatkan harga saham dan nilai perusahaan. Penjelasan tersebut diperkuat dengan adanya kebijakan dividen. Dengan adanya pembayaran dividen yang diinginkan pemegang saham, kesempatan untuk melakukan investasi oleh manajer dengan kas menjadi berkurang. Agar perusahaan mampu menjaga aliran kas di masa yang akan datang, perusahaan perlu meningkatkan penggunaan hutang.

Penelitian oleh Martini dan Riharjo (2014) yang mengatakan bahwa kebijakan dividen memperkuat pengaruh leverage terhadap nilai perusahaan. Berbeda dengan penelitian oleh Mahendra et al., (2012) yang menyatakan kebijakan dividen tidak memoderasi pengaruh leverage terhadap nilai perusahaan.
$\mathrm{H}_{4}$ : Kebijakan dividen memoderasi pengaruh leverage terhadap nilai perusahaan.

\section{Pengaruh Aktivitas Terhadap Nilai Perusahaan}

Menurut Harahap (2015:308), Rasio aktivitas menggambarkan keseluruhan kegiatan yang dilakukan oleh perusahaan dalam menjalankan operasionalnya, baik kegiatan penjualan, pembelian, dan kegiatan lainnya. Rasio ini mengukur kinerja manajemen dalam menjalankan perusahaan untuk menghasilkan pendapatan dan meningkatkan profitabilitas. Semakin tinggi perputaran total aset suatu perusahaan maka akan menghasilkan tingkat profitabilitas perusahaan yang tinggi. Bagi investor, hal tersebut mengindikasikan tingkat pengembalian akan meningkat sehingga memicu investor membeli harga saham. Ketika permintaan saham meningkat, harga saham menjadi tinggi mencerminkan nilai perusahaan yang tinggi.

Penelitian mengenai pengaruh aktivitas berpengaruh terhadap nilai perusahaan diteliti oleh Rinnaya et al., (2016). Hasil dari penelitian tersebut adalah aktivitas berpengaruh terhadap nilai perusahaan. Serta penelitian oleh Martani et al (2009) yang mengatakan bahwa rasio aktivitas berpengaruh terhadap nilai perusahaan. berbeda dengan hasil penelitian oleh Sianturi (2015) yang menyatakan bahwa aktivitas tidak berpengaruh terhadap nilai perusahaan.

$\mathrm{H}_{5}$ : Aktivitas berpengaruh terhadap nilai perusahaan.

\section{Pengaruh Aktivitas Terhadap Nilai Perusahaan Dengan Kebijakan Dividen Sebagai Variabel Moderating}

Teori kebijakan dividen mampu secara signifikan memoderasi pengaruh aktivitas terhadap nilai perusahaan. fleksibiltas sumber daya perusahaan lebih besar akan memperbesar kemampuan perusahaan dalam membayar dividen. Aktivitas menggambarkan sejauh mana suatu perusahaan mempergunakan sumber daya yang dimilikinya guna memnunjang aktivitas 
perusahaan, di mana penggunaan aktivitas dilakukan secara sangat maksimal dengan maksud memperoleh hasil yang maksimal.

Penelitian mengenai kebijakan dividen memoderasi pengaruh rasio aktivitas terhadap nilai perusahaan dilakukan oleh Taslim (2016), hasil penelitian menunjukan bahwa kebijakan dividen memoderasi pengaruh aktivitas terhadap nilai perusahaan. Berbeda dengan penelitian oleh Adibah (2015) yang menyatakan bahwa kebijakan dividen tidak memoderasi pengaruh aktivitas terhadap nilai perusahaan.

$\mathrm{H}_{6}$ : Kebijakan dividen memoderasi pengaruh aktivitas terhadap nilai perusahaan.

\section{Pengaruh Profitabilitas Terhadap Nilai Perusahaan}

Rasio profitabilitas yakni rasio yang menilai kemampuan perusahaan dalam mencari keuntungan (Kasmir, 2016:196). Rasio ini dapat juga memberikan ukuran tingkat efektivitas manajemen suatu perusahaan. Hal ini ditunjukkan oleh adanya laba yang dihasilkan dari penjualan dan pendapatan investasi. Inti dari penggunaan rasio ini adalah untuk menunjukkan efisiensi perusahaan (Kasmir, 2016:196).

Penelitian oleh Kushartono dan Nurhasanah (2017), Rinnaya et al., (2016), Sianturi (2015), Fadli (2015) serta Chen dan Chen (2011) yang mengatakan bahwa profitabilitas berpengaruh terhadap nilai perusahaan. Sedangkan penelitian oleh Adibah (2015) dan Anzlina dan Rustam (2013) menyatakan bahwa profitabilitas tidak berpengaruh terhadap nilai perusahaan.

\section{$\mathrm{H}_{7}$ : Profitabilitas berpengaruh terhadap nilai perusahaan}

\section{Pengaruh Profitabilitas Terhadap Nilai Perusahaan Dengan Kebijakan Dividen Sebagai Variabel Moderating}

Berdasarkan signaling theory dalam Hanafi (2014:371) pasar akan menginterpertasikan pembayaran dividen sebagai sinyal tentang prospek cerah perusahaan dimasa yang akan datang. Dengan adanya pembayaran dividen yang meningkat kepada pemegang saham, investor memprekdisikan laba yang telah didapatkan oleh perusahaan akan berlanjut atau bahkan semakin baik. Semakin baik prospek perusahaan maka perusahaan dianggap menguntungkan oleh investor, akibatnya investor tertarik untuk membeli saham perusahaan dan meningkatkan permintaan saham perusahaan. Hal ini akan meningkatkan harga saham perusahaan. Harga saham yang tinggi mencerminkan nilai perusahaan yang tinggi.

Penelitian oleh Mery (2017), Lestari (2017), Fadhli (2015), serta Erlangga (2009), yang mengatakan bahwa kebijakan dividen dapat memperkuat pengaruh profitabilitas terhadap nilai perusahaan. Sedangkan Penelitian oleh Adibah (2015) dan Mahendra et al., (2012) menyatakn bahwa kebijakan dividen tidak memoderasi pengaruh profitabilitas terhadap nilai perusahaan.

\section{$\mathrm{H}_{8}$ : Kebijakan dividen memoderasi pengaruh} profitabilitas terhadap nilai perusahaan.

\section{Metode Penelitian}

Penelitian ini termasuk dalam jenis penelitian korelasi. Menurut Faenkel et al., (2008:328) di mana penelitian korelasi atau korelasional adalah suatu penelitian untuk mengetahui hubungan dan tingkat hubungan antara dua variabel atau lebih tanpa ada upaya untuk mempengaruhi variabel tersebut sehingga tidak terdapat manipulasi variabel. Dimana terdapat satu atau lebih variabel independen $(\mathrm{X})$ yang mempengaruhi variabel dependen $(\mathrm{Y})$.

Penelitian ini dilakukan pada perusahaan sektor Manufaktur yang terdaftar di BEI periode 2013-2017. Populasi pada penelitian ini adalah perusahaan sektor Manufaktur sebanyak 147 perusahaan. Pengambilan sampel dilakukan dengan teknik purposive sampling. Sebanyak 66 perusahaan sektor manufaktur yang terpilih sebagai sampel penelitian ini.

Studi pustaka, penelitian ini mengkaji teori yang diperoleh dari literatur, artikel jurnal dan hasil penelitian terdahulu sehingga peneliti dapat memahami literatur yang berkaitan dengan penelitian yang 
bersangkutan. Pada penelitian ini, peneliti memperoleh data laporan keuangan dan harga sahamperiode 2013-2017 secara tahunan dari Galeri Investasi Bursa Efek Indonesia (GIBEI) STIESIA Surabaya.

Metode analisis data yang digunakan untuk mengetahui dan memperoleh gambaran mengenai pengaruh kinerja keuangan terhadap nilai perusahaan dengan kebijakan dividen sebagai variabel moderating pada perusahaan Manufaktur di Bursa Efek Indonesia Tahun 2013-2017 dengan menggunakan model analisis regresi dengan bantuan SPSS (Statistical Product and Service Solution). Untuk menguji pengaruh variabel independen dengan variabel dependen digunakan analisis regresi dan Moderated Regression Analysis (MRA). Menurut Gujarati (2007:7), pada dasarnya analisis regresi merupakan studi mengenai ketergantungan variabel dependen dengan satu atau lebih variabel independennya, dengan tujuan untuk mengestimasi atau memprediksi rata-rata populasi atau nilai rata-rata variabel dependen berdasarkan nilai variabel yang diketahui.

Menurut Ghozali (2013: 229), Moderated Regression Analysis (MRA) adalah pendekatan analitik yang mempertahankan integritas sampel dan memberikan dasar untuk mengontrol pengaruh variabel moderator. Uji MRA disebut juga sebagai uji interaksi, dimana uji ini dilakukan dengan mengalikan variabel moderasi dengan variabel independen. Apabila variabel hasil tersebut signifikan maka dapat disimpulkan bahwa variabel moderasi mampu memoderasi hubungan kausal antara variabel independen terhadap variabel dependen. Persamaan Regresi yang digunakan dalam penelitian ini adalah sebagai berikut :

$$
\begin{aligned}
& Y=\alpha+b_{1} \cdot X_{1}+e \\
& Y=\alpha+b_{1} X_{1}+b_{2} \cdot Z+b_{3} X_{1} \cdot Z+e \\
& Y=\alpha+b_{1} \cdot X_{2}+e \\
& Y=\alpha+b_{1} X_{2}+b_{2} \cdot Z+b_{3} X_{2} \cdot Z+e \\
& Y=\alpha+b_{1} \cdot X_{3}+e \\
& Y=\alpha+b_{1} X_{3}+b_{2} \cdot Z+b_{3} X_{3} \cdot Z+e \\
& Y=\alpha+b_{1} \cdot X_{4}+e \\
& Y=\alpha+b_{1} X_{4}+b_{2} \cdot Z+b_{3} X_{4} \cdot Z+e
\end{aligned}
$$

Keterangan :

$$
\begin{aligned}
& \mathrm{Y}=\text { Nilai perusahaan } \\
& \alpha \quad=\text { Konstanta } \\
& \mathrm{b}_{1}, \mathrm{~b}_{2}, \mathrm{~b}_{3} \quad=\text { Koefisien regresi } \\
& \mathrm{X}_{1}, \mathrm{X}_{2}, \mathrm{X}_{3}, \mathrm{X}_{4}=\text { Variabel Independen } \\
& \mathrm{Z} \quad=\text { Kebijakan dividen } \\
& \mathrm{X}_{\mathrm{i}} \cdot \mathrm{Z} \quad=\text { Variabel Interaksi } \\
& \mathrm{e}=\text { Error Term, yaitu tingkat } \\
& \text { kesalahan penduga dalam } \\
& \text { penelitian }
\end{aligned}
$$

\section{Hasil Penelitian Dan Pembahasan}

\section{Gambaran Umum Objek Penelitian}

Objek penelitian ini menggunakan populasi perusahaan sektor Manufaktur yang terdaftar di Bursa Efek Indonesia (BEI) periode 2013-2017 sebanyak 147 perusahaan. Berdasarkan metode purposive sampling yang telah dilakukan, sebanyak 66 perusahaan Manufaktur yang dapat dijadikan sebagai sampel penelitian.

\section{Statistik Deskriptif}

Tabel 2

Statistik Deskriptif

\begin{tabular}{llrrrr}
\hline \hline & N & \multicolumn{1}{c}{ Minimum } & Maximum & \multicolumn{1}{c}{ Mean } & \multicolumn{1}{c}{ Std.Deviation } \\
\hline \hline PBV & 330 & 0.00 & 299.68 & 4.35 & 18.35275 \\
CR & 330 & 27.56 & 1516.45 & 259.37 & 224.02295 \\
DER & 330 & 0.06 & 7.4 & 0.94 & 0.8656 \\
TATO & 330 & 0.04 & 74.84 & 9.01 & 10.16671 \\
ROA & 330 & 18.63 & 410.91 & 112.66 & 58.31633 \\
DPR & 330 & 0.00 & 9989.4 & 60.72 & 549.87925 \\
\hline Sumber : Data GIBEI diolah & & & &
\end{tabular}

Dari tabel 2 diatas, nilai rata-rata variabel nilai perusahaan (PBV) sebesar 4,35 persen dengan standar deviasi sebesar 18,35 persen. PBV terendah sebesar 0,00 persen dan nilai 
tertinggi sebesar 299,68 persen. Variabel likuiditas (CR) memiliki nilai rata-rata sebesar 259,37 persen dengan standar deviasi sebesar 224,02 persen. CR terendah sebesar 27,56 persendan nilai tertinggi sebesar 1516,45 persen. Variabel leverage (DER) memiliki nilai rata-rata sebesar 0,94 persen dengan standar deviasi sebesar 0,87 persen. DER terendah sebesar 0,06 persen dan nilai tertinggi sebesar 7,40 persen. Variabel aktivitas (TATO) memiliki nilai rata-rata sebesar 9,01 persen dengan standar deviasi sebesar 10,17 persen. TATO terendah sebesar 0,04 persen dan nilai tertinggi sebesar 74,84 persen. Variabel profitabilitas (ROA) memiliki nilai rata-rata sebesar 112,66 persen dengan standar deviasi sebesar 58,32 persen. ROA terendah sebesar 18,63 persen dan nilai tertinggi sebesar 410,91 persen. Variabel kebijakan dividen (DPR) memiliki nilai ratarata sebesar 60,72 persen dengan standar deviasi sebesar 549,88 persen. DPR terendah sebesar 0,00 persen dengan nilai tertinggi sebesar 9989,40 persen.

\section{Persamaan Regresi}

Model persamaan regresi linier adalah sebagai berikut:

$\mathrm{Y}=-4,189-0,003 \mathrm{CR}+2,801 \mathrm{DER}+0,026$ $\mathrm{TATO}+0,431 \mathrm{ROA}+\mathrm{e}$.

Berdasarkan model regresi di atas dapat dijelaskan bahwa :

1. Nilai konstanta sebesar - 4,189. Artinya, jika likuiditas (CR), leverage (DER), aktivitas (TATO), dan profitabilitas (ROA) sama dengan nol, maka nilai perusahaan akan mengalami penurunan sebesar 4,189 satuan.

2. Nilai koefisien regresi variabel likuiditas (CR) negatif sebesar 0,003 . Nilai negatif berarti terdapat hubungan yang berlawanan arah, artinya jika likuiditas (CR) mengalami peningkatan sebesar satu satuan, maka nilai perusahaan (PBV) akan mengalami penurunan sebesar 0,003 satuan dengan asumsi variabel lain besarnya konstan. Dan sebaliknya.

3. Nilai koefisien regresi variabel leverage (DER) positif sebesar 2,801. Nilai positif berarti terdapat hubungan yang searah, artinya jika leverage (DER) mengalami peningkatan sebesar satu satuan, maka nilai perusahaan (PBV) juga akan mengalami kenaikan sebesar 2,801 satuan dengan asumsi variabel lain besarnya konstan. Dan sebaliknya.

4. Nilai koefisien regresi variabel aktivitas (TATO) positif sebesar 0,026. Nilai positif berarti terdapat hubungan yang searah, artinya jika aktivitas (TATO) mengalami peningkatan sebesar satu satuan, maka nilai perusahaan (PBV) juga akan mengalami kenaikan sebesar 0,026 satuan dengan asumsi variabel lain besarnya konstan. Dan sebaliknya.

5. Nilai koefisien regresi variabel profitabilitas (ROA) positif sebesar 0,431. Nilai positif berarti terdapat hubungan yang searah, artinya jika profitabilitas (ROA) mengalami peningkatan sebesar satu satuan, maka nilai perusahaan (PBV) juga akan mengalami kenaikan sebesar 0,431 satuan dengan asumsi variabel lain besarnya konstan. Dan sebaliknya.

Model persamaan Moderated Regression Analysis (MRA) adalah sebagai berikut:

$\mathrm{Y}=-2,740+0,003 \mathrm{CR}+2,265 \mathrm{DER}+0,026$ TATO + 0,060 ROA + 0,008 DPR + 0,000 CR.DPR - 0,001 DER.DPR - 7,066 TATO.DPR + 0,006 ROA.DPR + e.

Berdasarkan model regresi di atas dapat dijelaskan bahwa :

1. Nilai konstanta sebesar - 2,740. Artinya, jika semua variabel sama dengan nol, maka nilai perusahaan akan mengalami penurunan sebesar 2,740 satuan.

2. Nilai koefisien regresi variabel interaksi antara likuiditas dengan kebijakan dividen (CR.DPR) positif sebesar 0,000. Nilai positif berarti terdapat hubungan yang searah, artinya jika variabel interaksi antara likuiditas dengan kebijakan dividen (CR.DPR) mengalami peningkatan sebesar satu satuan, maka pengaruh likuiditas terhadap nilai perusahaan (PBV) juga akan meningkat sebesar 0,000 satuan dengan asumsi variabel lain besarnya konstan dan sebaliknya.

3. Nilai koefisien regresi variabel interaksi antara leverage dengan kebijakan dividen (DER.DPR) negatif sebesar 0,001. Nilai negatif berarti terdapat hubungan yang berlawanan arah, artinya jika variabel 
interaksi antara leverage dengan kebijakan dividen (DER.DPR) mengalami peningkatan sebesar satu satuan, maka pengaruh leverage terhadap nilai perusahaan (PBV) akan menurun sebesar 0,001 satuan dengan asumsi variabel lain besarnya konstan dan sebaliknya.

4. Nilai koefisien regresi variabel interaksi antara aktivitas dengan kebijakan dividen (TATO.DPR) negatif sebesar 7,066. Nilai negatif berarti terdapat hubungan yang berlawanan arah, artinya jika variabel interaksi antara aktivitas dengan kebijakan dividen (TATO.DPR) mengalami peningkatan sebesar satu satuan, maka pengaruh aktivitas terhadap nilai perusahaan (PBV) akan menurun sebesar 7,066 satuan dengan asumsi variabel lain besarnya konstan dan sebaliknya.

5. Nilai koefisien regresi variabel interaksi antara profitabilitas dengan kebijakan dividen (ROA.DPR) positif sebesar 0,006. Nilai positif berarti terdapat hubungan yang searah, artinya jika variabel interaksi antara profitabilitas dengan kebijakan dividen (TATO.DPR) mengalami peningkatan sebesar satu satuan, maka pengaruh profitabilitas terhadap nilai perusahaan (PBV) juga akan meningkat sebesar 0,006 satuan dengan asumsi variabel lain besarnya konstan dan sebaliknya.

\section{Uji Kelayakan Model}

Tabel 3

Hasil Uji Kelayakan Model

\begin{tabular}{lrrrcr}
\hline \hline Model & Sum of Squares & Df & Mean Square & F & \multicolumn{1}{l}{ Sig. } \\
\hline \hline Regression & 10824.406 & 5 & 2164.881 & 7.015 & $.000^{\mathrm{b}}$ \\
Residual & 99990.459 & 324 & 308.613 & & \\
\hline Total & 110814.865 & 329 & & & \\
\hline
\end{tabular}

a. Dependent Variable: PBV

b. Predictors: (Constant), CR, DER, TATO,ROA, DPR

Berdasarkan tabel 3 diatas, hasil uji kelayakan model menunjukkan bahwa analisis regresi linier dalam penelitian ini memiliki nilai signifikansi sebesar 0,000 . Dimana hasil tersebut menyatakan nilai sig $0,000<0,05$, dan dapat disimpulkan secara statistik variabel likuiditas (CR), leverage (DER), aktivitas (TATO), dan profitabilitas (ROA) serta kebijakan dividen (DPR) sebagai variabel moderating terbukti merupakan variabel yang layak/tepat untuk menjelaskan terjadinya variasi pada nilai perusahaan

\section{Uji Hipotesis}

Tabel 4

Pengaruh Kinerja Keuangan Terhadap Nilai Perusahaan Coefficients $^{\mathrm{a}}$

\begin{tabular}{|c|c|c|c|c|c|}
\hline \multirow[b]{2}{*}{ Model } & \multicolumn{2}{|c|}{ Unstandardized Coefficients } & \multicolumn{2}{|c|}{ Standardized Coefficients } & \multirow[b]{2}{*}{ Sig. } \\
\hline & B & Std. Error & Beta & $\mathrm{t}$ & \\
\hline (Constant) & -4.189 & 3.023 & & -1.386 & .167 \\
\hline $\mathrm{CR}$ & -.003 & .005 & -.041 & -.686 & .494 \\
\hline DER & 2.801 & 1.242 & .132 & 2.256 & .025 \\
\hline TATO & .026 & .020 & .082 & 1.326 & .186 \\
\hline ROA & .431 & .113 & .239 & 3.811 & .000 \\
\hline
\end{tabular}

a. Dependent Variable: PBV 
Berdasarkan hasil pengujian hipotesis tabel 4 di atas, maka dapat dijelaskan sebagai berikut:

\section{Hasil pengujian hipotesis pertama}

Hipotesis 1 : Likuiditas berpengaruh terhadap nilai perusahaan

Berdasarkan tabel 4 di atas dengan menggunakan tingkat signifikansi sebesar $\alpha=$ 0,05 dari variabel likuiditas yang diproksikan dengan current ratio (CR), diperoleh tingkat signifikansi sebesar 0,494 lebih besar dari tingkat signifikansi $0,05 \quad(0,494>0,05)$ sehingga hipotesis pertama ditolak. Jadi, hal ini berarti bahwa variabel likuiditas (CR) berpengaruh tidak signifikan terhadap nilai perusahaan (PBV).

\section{Hasil pengujian hipotesis ketiga}

Hipotesis 3 : Leverage berpengaruh terhadap nilai perusahaan

Berdasarkan tabel 4 di atas dengan menggunakan tingkat signifikansi sebesar $\alpha=$ 0,05 dari variabel leverage yang diproksikan dengan debt to equity ratio (DER), diperoleh tingkat signifikansi sebesar 0,025 lebih kecil dari tingkat signifikansi $0,05(0,025<0,05)$ sehingga hipotesis ketiga diterima. Jadi, hal ini berarti bahwa variabel leverage (DER) berpengaruh signifikan terhadap nilai perusahaan (PBV).

\section{Hasil pengujian hipotesis kelima}

Hipotesis 5 : Aktivitas berpengaruh terhadap nilai perusahaan

Berdasarkan tabel 4 di atas dengan menggunakan tingkat signifikansi sebesar $\alpha=$ 0,05 dari variabel aktivitas yang diproksikan dengan total assets turnover (TATO), diperoleh tingkat signifikansi sebesar 0,186 lebih besar dari tingkat signifikansi 0,05 $(0,186>0,05)$ sehingga hipotesis kelima ditolak. Jadi, hal ini berarti bahwa variabel aktivitas (TATO) berpengaruh tidak signifikan terhadap nilai perusahaan (PBV).

\section{Hasil pengujian hipotesis ketujuh}

Hipotesis 7 : Profitabilitas berpengaruh terhadap nilai perusahaan

Berdasarkan tabel 4 di atas dengan menggunakan tingkat signifikansi sebesar $\alpha=$ 0,05 dari variabel profitabilitas yang diproksikan dengan return on assets (ROA), diperoleh tingkat signifikansi sebesar 0,000 lebih kecil dari tingkat signifikansi 0,05 $(0,000<0,05)$ sehingga hipotesis ketujuh diterima. Jadi, hal ini berarti bahwa variabel profitabilitas (ROA) berpengaruh signifikan terhadap nilai perusahaan (PBV).

Tabel 5

Uji MRA

Coefficients $^{\mathrm{a}}$

\begin{tabular}{lrrcrc}
\hline Model & \multicolumn{2}{c}{$\begin{array}{c}\text { Unstandardized Coefficients } \\
\text { B }\end{array}$} & $\begin{array}{c}\text { Standardized Coefficients } \\
\text { Std. Error }\end{array}$ & T & Sig. \\
\hline \hline (Constant) & -2.740 & 3.566 & & & \\
CR & .003 & .006 & .038 & -.768 & .443 \\
DER & 2.265 & 1.463 & .107 & .547 & .585 \\
TATO & .026 & .023 & .083 & 1.548 & .123 \\
ROA & .060 & .183 & .033 & 1.120 & .263 \\
DPR & .008 & .064 & .250 & .327 & .744 \\
CR.DPR & .000 & .000 & -4.481 & .130 & .897 \\
DER.DPR & -.001 & .022 & -.008 & -1.974 & .049 \\
TATO.DPR & -7.066 & .000 & -.496 & -.048 & .961 \\
ROA.DPR & .006 & .003 & 4.758 & -.152 & .879 \\
\hline
\end{tabular}

a. Dependent Variable: PBV

Berdasarkan hasil pengujian hipotesis dengan moderated regression analysis (MRA) tabel 9 di atas, maka dapat dijelaskan sebagai berikut: 


\section{Hasil pengujian hipotesis kedua}

Hipotesis kedua : Kebijakan dividen memoderasi pengaruh likuiditas terhadap nilai perusahaan.

Berdasarkan tabel 5 di atas dengan menggunakan tingkat signifikansi sebesar $\alpha=$ 0,05 dari variabel interaksi antara likuiditas dengan kebijakan dividen yang diproksikan dengan CR.DPR, diperoleh tingkat signifikansi sebesar 0,049 lebih kecil dari tingkat signifikansi $0,05 \quad(0,049<0,05)$ sehingga hipotesis kedua diterima. Jadi, hal ini berarti bahwa variabel kebijakan dividen memoderasi pengaruh likuiditas terhadap nilai perusahaan.

\section{Hasil pengujian hipotesis keempat}

Hipotesis keempat : Kebijakan dividen memoderasi pengaruh leverage terhadap nilai perusahaan.

Berdasarkan tabel 5 di atas dengan menggunakan tingkat signifikansi sebesar $\alpha=$ 0,05 dari variabel interaksi antara leverage dengan kebijakan dividen yang diproksikan dengan DER.DPR, diperoleh tingkat signifikansi sebesar 0,961 lebih besar dari tingkat signifikansi $0,05 \quad(0,961>0,05)$ sehingga hipotesis keempat ditolak. Jadi, hal ini berarti bahwa variabel kebijakan dividen tidak memoderasi pengaruh leverage terhadap nilai perusahaan.

\section{Hasil pengujian hipotesis keenam}

Hipotesis keenam : Kebijakan dividen memoderasi pengaruh aktivitas terhadap nilai perusahaan.

Berdasarkan tabel 5 di atas dengan menggunakan tingkat signifikansi sebesar $\alpha=$ 0,05 dari variabel interaksi antara aktivitas dengan kebijakan dividen yang diproksikan dengan TATO.DPR, diperoleh tingkat signifikansi sebesar 0,879 lebih besar dari tingkat signifikansi $0,05 \quad(0,879>0,05)$ sehingga hipotesis keenam ditolak. Jadi, hal ini berarti bahwa variabel kebijakan dividen tidak memoderasi pengaruh aktivitas terhadap nilai perusahaan.

\section{Hasil pengujian hipotesis kedelapan}

Hipotesis kedelapan : Kebijakan dividen memoderasi pengaruh profitabilitas terhadap nilai perusahaan.
Berdasarkan tabel 5 di atas dengan menggunakan tingkat signifikansi sebesar $\alpha=$ 0,05 dari variabel interaksi antara profitabilitas dengan kebijakan dividen yang diproksikan dengan ROA.DPR, diperoleh tingkat signifikansi sebesar 0,027 lebih kecil dari tingkat signifikansi $0,05(0,027<0,05)$ sehingga hipotesis kedelapan diterima. Jadi, hal ini berarti bahwa variabel kebijakan dividen memoderasi pengaruh profitabilitas terhadap nilai perusahaan.

\section{ANALISIS DAN PEMBAHASAN}

\section{Hasil Pengaruh Likuiditas Terhadap Nilai Perusahaan}

Berdasarkan hasil penelitian, likuiditas (CR) tidak dipergunakan untuk memprediksi nilai perusahaan. Dengan demikian penelitian ini menolak hipotesis pertama yang menyatakan likuiditas berpengaruh terhadap nilai perusahaan. Dapat dikatakan seorang investor dalam melakukan investasi tidak memperhatikan rasio likuiditas (CR) yang dimiliki perusahaan.Karena rasio likuiditas hanya menunjukkan kemampuan perusahaan dalam menutupi hutang jangka pendek perusahaan dengan aktiva lancar perusahaan, hal tersebut menunjukkan bahwa likuiditas berorientasi pada jangka pendek, sedangkan nilai perusahaan berorientasi pada jangka panjang sehingga tidak menunjukkan adanya pengaruh yang signifikan antara likuiditas dengan nilai perusahaan.

Hasil penelitian ini sesuai dengan penelitian oleh Damayanti et al., (2018) dan Nurhayati (2013) menyatakan likuiditas tidak berpengaruh terhadap nilai perusahaan. Hasil penelitian ini tidak sesuai dengan hasil penelitian Anzlina dan Rustam (2013) yang menyatakan bahwa likuiditas berpengaruh terhadap nilai perusahaan.

\section{Hasil Kebijakan Dividen Memoderasi Pengaruh Likuiditas Terhadap Nilai Perusahaan}

Berdasarkan hasil penelitian, dapat disimpulkan bahwa kebijakan dividen memoderasi pengaruh likuiditas terhadap nilai perusahaan. Dengan demikian penelitian ini menerima hipotesis kedua yang menyatakan kebijakan dividen memoderasi pengaruh likuiditas terhadap nilai perusahaan. Dengan 
adanya kebijakan dividen perusahaan mampu menyeimbangkan kas perusahaan dalam aktifitas pendanaannya demi menjaga likuiditas perusahaan. Perusahaan dengan tingkat likuiditas yang baik mampu mempengaruhi besarnya nilai perusahaan bila perusahaan tersebut membagikan dividen sebagai ukuran dari kemakmuran pemegang saham.

Hasil penelitian ini sesuai dengan penelitian oleh Lestari (2017) dan Sukoco (2013), yang menyatakan bahwa kebijakan dividen memoderasi pengaruh likuiditas terhadap nilai perusahan. Hasil penelitian ini tidak sesuai dengan hasil penelitian oleh Mahendra et al., (2012), yang menyatakan bahwa kebijakan dividen tidak memoderasi pengaruh likuiditas terhadap nilai perusahaan.

\section{Hasil Pengaruh Leverage Terhadap Nilai Perusahaan}

Berdasarkan hasil penelitian, dapat disimpulkan bahwa leverage berpengaruh signifikan terhadap nilai perusahaan. Hal ini berarti leverage (DER) dipergunakan untuk memprediksi nilai perusahaan. Dengan demikian penelitian ini menerima hipotesis ketiga, yang menyatakan leverage berpengaruh terhadap nilai perusahaan. Hasil penelitian ini menunjukkan bahwa penggunaan leverage (DER) mampu meningkatkan nilai perusahaan karena dalam perhitungan pajak, bunga yang dikenakan akibat penggunaan hutang dikurangkan terlebih dahulu, sehingga mengakibatkan perusahaan memperoleh keringanan pajak.

Dalam penelitian ini, tingginya leverage suatu perusahaan dapat dimanfaatkan untuk memperoleh profit/keuntungan yang lebih tinggi dengan menggunakan sumber modal dari hutang atau aset-aset yang dibiayai menggunakan hutang, hal tersebut dapat menjadikan perusahaan dapat secara maksimal menjalankan usahanya sehingga profit yang diperoleh perusahaan akan meningkat. Hal tersebut akan direspon oleh investor sebagai sinyal positif dalam kegiatan investasinya.

Hasil penelitian ini sesuai dengan penelitian oleh Lestari (2017) dan Sutama dan Lisa (2018) menyatakan bahwa leverage berpengaruh positif dan signifikan terhadap nilai perusahaan. Berbeda dengan hasil penelitian yang dilakukan oleh Anzlina dan Rustam (2017), yang menyatakan bahwa leverage tidak berpengaruh terhadap nilai perusahaan.

\section{Hasil Kebijakan Dividen Memoderasi Pengaruh Leverage Terhadap Nilai Perusahaan}

Berdasarkan hasil penelitian, dapat disimpulkan bahwa kebijakan dividen tidak memoderasi pengaruh leverage terhadap nilai perusahaan. Dengan demikian penelitian ini menolak hipotesis keempat, yang menyatakan kebijakan dividen memoderasi pengaruh leverage terhadap nilai perusahaan. Dimana tinggi rendahnya dividen yang dibayarkan kepada pemegang saham, tidak berkaitan dengan tinggi rendahnya nilai perusahaan. Hal ini sesuai dengan teori yang dikemukakan oleh Miller dan Modligiani yang menyatakan bahwa kebijakan dividen tidak dipengaruhi nilai perusahaan karena menurut mereka rasio pembayaran dividen hanyalah rincian dan tidak mempengaruhi kesejahteraan pemegang saham.

Hasil penelitian ini sesuai dengan penelitian oleh Fadhli (2015) yang menyatakan bahwa kebijakan dividen tidak memoderasi pengaruh leverage terhadap nilai perusahaan. Akan tetapi, hasil penelitian ini tidak sesuai dengan penelitian oleh Martini dan Riharjo (2014) yang mengatakan bahwa kebijakan dividen memoderasi pengaruh leverage terhadap nilai perusahaan.

\section{Hasil Pengaruh Aktifitas Terhadap Nilai Perusahaan}

Berdasarkan hasil penelitian, dapat disimpulkan bahwa aktivitas berpengaruh tidak signifikan terhadap nilai perusahaan. Hal ini berarti aktivitas (TATO) tidak dipergunakan untuk memprediksi nilai perusahaan. Dengan demikian penelitian ini menolak hipotesis kelima, yang menyatakan rasio aktivitas (TATO) berpengaruh terhadap nilai perusahaan (PBV).

Hasil penelitian mengindikasikan bahwa investor tidak memperhatikan rasio aktivitas (TATO) yang dimiliki perusahaan. Hal tersebut dikarenakan fenomena penurunan nilai perusahaan terjadi karena adanya kenaikan hutang perusahaan yang digunakan 
untuk biaya operasional perusahaan. Jadi, meskipun rasio aktivitas pada perusahaan manufaktur mengalami kenaikan tetapi hutang yang harus dibayar perusahaan tingi maka nilai perusahaan akan menurun, sehingga tidak menghasilkan tingkat profitabilitas perusahaan yang tinggi.

Hasil penelitian ini sesuai dengan penelitian oleh Taslim (2016) dan Sianturi (2015) yang menyatakan bahwa rasio aktivitas tidak berpengaruh terhadap nilai perusahaan. Sedangkan hasil penelitian ini tidak sesuai dengan hasil penelitian oleh Rinnaya et al., (2016), yang menyatakan bahwa aktivitas berpengaruh terhadap nilai perusahaan.

\section{Hasil Kebijakan Dividen Memoderasi Pengaruh Aktivitas Terhadap Nilai Perusahaan}

Berdasarkan hasil penelitian, dapat disimpulkan bahwa kebijakan dividen tidak memoderasi pengaruh aktivitas terhadap nilai perusahaan. Dengan demikian, penelitian ini menolak hipotesis keenam, yang menyatakan kebijakan dividen memoderasi pengaruh aktivitas terhadap nilai perusahaan. Penyebabnya, karena efisiensi penggunaan keseluruhan aktiva perusahaan dalam menghasilkan volume penjualan dengan pembayaran dividen tidak berpengaruh terhadap laba yang dihasilkan aset perusahaan.

Dimana rasio aktivitas pada perusahaan manufaktur mengalami kenaikann namun laba yang dihasilkan perusahaan justru menurun. Hal tersebut disebabkan oleh hutang yang harus dibayar perusahaan juga tinggi.

Hasil penelitian ini sesuai dengan hasil penelitian oleh Adibah (2015) menyatakan bahwa kebijakan dividen tidak memoderasi pengaruh aktivitas terhadap nilai perusahaan. Hasil penelitian ini tidak sesuai dengan penelitian oleh Taslim (2016), yang menyatakan bahwa kebijakan dividen mampu memoderasi pengaruh aktivitas terhadap nilai perusahaan.

\section{Hasil Pengaruh Profitabilitas Terhadap Nilai Perusahaan}

Berdasarkan hasil penelitian, dapat disimpulkan bahwa profitabilitas berpengaruh signifikan terhadap nilai perusahaan. Hal ini berarti profitabilitas (ROA) dipergunakan untuk memprediksi nilai perusahaan. Dengan demikian, penelitian ini menerima hipotesis ketujuh, yang menyatakan profitabilitas (ROA) berpengaruh signifikan terhadap nilai perusahaan (PBV).

Hasil penelitian mengindikasikan bahwa profitabilitas menunjukkan tingkat keuntungan bersih yang mampu diraih oleh perusahaan pada saat menjalankan operasinya. Keuntungan yang layak dibagikan kepada pemegang saham adalah keuntungan setelah bunga dan pajak, sehingga dengan profitabilitas yang tinggi dapat memberikan nilai tambah kepada nilai perusahaannya yang tercermin pada harga saham perusahaan tersebut.

Hasil penelitian ini sesuai dengan penelitian yang dilakukan oleh Kushartono dan Nurhasanah (2017) dan Mahendra et al., (2012) menyatakan profitabilitas berpengaruh terhadap nilai perusahaan. Hasil penelitian ini tidak sesuai dengan hasil penelitian oleh Adibah (2015), yang menyatakan bahwa profitabilitas tidak berpengaruh terhadap nilai perusahaan.

\section{Hasil Kebijakan Dividen Memoderasi Pengaruh Profitabilitas Terhadap Nilai Perusahaan}

Berdasarkan hasil penelitian, dapat disimpulkan bahwa kebijakan dividen memoderasi pengaruh profitabilitas terhadap nilai perusahaan. Dengan demikian, penelitian ini menerima hipotesis kedelapan, yang menyatakan kebijakan dividen memoderasi pengaruh profitabilitas terhadap nilai perusahaan. Dimana profitabilitas merupakan determinan utama sebagai bahan pertimbangan perusahaan membayar dividen, semakin tinggi profitabilitas menunjukkan semakin baik manajemen dalam menjalankan operasi perusahaan. Hal tersebut menjadi bahan pertimbangan bagi investor luar untuk menanamkan investasinya pada perusahaan.

Hasil penelitian ini sesuai dengan penelitian yang dilakukan Taslim (2016), yang menyatakan bahwa kebijakan dividen mampu memoderasi pengaruh profitabilitas terhadap nilai perusahaan. Hasil penelitian ini tidak sesuai dengan penelitian oleh Adibah (2015), yang menyatakan bahwa kebijakan 
dividen tidak mampu memoderasi pengaruh profitabilitas terhadap nilai perusahaan.

\section{Kesimpulan, Keterbatasan Dan Implikasi Hasil Penelitian}

1. Likuiditas berpengaruh negatif dan tidak signifikan terhadap nilai perusahaan. Ini ini dikarenakan likuiditas berorientasi pada jangka pendek, sedangkan nilai perusahaan berorientasi pada jangka panjang sehingga tidak menunjukkan adanya pengaruh yang signifikan antara likuiditas dengan nilai perusahaan.

2. Kebijakan dividen memoderasi pengaruh likuiditas terhadap nilai perusahaan. Dengan adanya kebijakan dividen perusahaan mampu menyeimbangkan kas perusahaan dalam aktifitas pendanaannya demi menjaga likuiditas perusahaan. Dimana perusahaan dengan tingkat likuiditas yang baik mampu mempengaruhi besarnya nilai perusahaan bila perusahaan tersebut membagikan dividen sebagai ukuran dari kemakmuran pemegang saham.

3. Leverage berpengaruh positif dan signifikan terhadap nilai perusahaan. Dengan adanya hutang maka dapat dapat dimanfaatkan untuk memperoleh profit yang lebih tinggi sehingga dapat menarik kepercayaan investor sehingga diharapkan bahwa prospek perusahaan di masa yang akan datang akan cerah. Selain itu, dengan adanya hutang dimaksudkan untuk mengurangi beban pajak atas perusahaan tersebut.

4. Kebijakan dividen tidak memoderasi pengaruh leverage terhadap nilai perusahaan. Masuknya kebijakan dviden tidak berkaitan dengan meningkatnya nilai perusahaan. Karena nilai perusahaan ditentukan hanya oleh kemampuan perusahaan menghasilkan laba dari asetaset perusahaan atau kebijakan investasinya.

5. Aktivitas berpengaruh positif dan tidak signifikan terhadap nilai perusahaan. Hal ini mengindikasikan bahwa investor tidak memperhatikan rasio aktivitas (TATO) yang dimiliki perusahaan. Hal tersebut dikarenakan fenomena penurunan nilai perusahaan terjadi karena adanya kenaikan hutang perusahaan atau besarnya penggunaan hutang yang digunakan untuk biaya operasional perusahaan.

6. Kebijakan dividen tidak memoderasi pengaruh aktivitas terhadap nilai perusahaan. Hal ini terjadi karena efisiensi penggunaan keseluruhan aktiva perusahaan dalam menghasilkan volume penjualan dengan pembayaran dividen tidak berpengaruh terhadap laba yang dihasilkan aset perusahaan.

7. Profitabilitas berpengaruh dan signifikan terhadap nilai perusahaan. Semakin tinggi profitabilitas maka nilai perusahaan semakin tinggi dan semakin rendah profitabilitas maka nilai perusahaan juga rendah.

Dalam penelitian ini, peneliti memiliki beberapa keterbatasan diantaranya :

1. Penelitian ini hanya menggunakan metode penelitian yang relatif pendek yakni 5 (lima) tahun.

2. Dalam penelitian ini hanya menggunakan 4 variabel independen, yakni likuiditas, leverage, aktivitas dan profitabilitas.

Beberapa saran yang dapat dikemukakan dari hasil penelitian ini adalah sebagai berikut:

1. Agar perusahaan lebih memperhatiakan tingkat likuiditas yang tidak terlalu tinggi sehingga kegiatan penyimpangan dalam penggunaan dana perusahaan dapat diantisipasi.

2. Perusahaan harus tetap mengendalikan tingkat leverage yang tinggi agar tidak masuk dalam kategori extreme leverage (utang ekstrim).

\section{DAFTAR REFERENSI}

Adibah, F. (2015). Pengaruh Kinerja Keuangan Terhadap Nilai Perusahaan Pertambangan Dengan Kebijakan Dividen Sebagai Variabel Moderating. Tesis. Sekolah Tinggi Ilmu Ekonomi Indonesia.

Anzlina, C. W. (2013). Pengaruh Tingkat Likuiditas, Solvabilitas, Aktivitas Dan Profitabilitas Terhadap Nilai Perusahaan Pada Perusahaan Real Estate Dan Property 
Di BEI Tahun 2006-2008. Jurnal Ekonomi. 16(2): 67-75.

Bank Indonesia. (2004). Surat Edaran Bank Indonesia Nomor 6/23/DPNP Perihal Sistem Penilaian Tingkat Kesehatan Bank. Diakses pada tanggal 4 Desember 2017. www.bi.go.id. Azwar, Saifuddin. 2013. Metode Penelitian. Cetakan XIV. Yogyakarta: Pustaka Pelajar

Brigham, E. F., \& Houston J. F. (2010). Dasar-Dasar manajemen Keuangan. Jakarta: Salemba empat.

Chen, L. J., \& Chen, S. Y. (2011). The Influence of Profitabily on Firm Value with Capital Strukture as The as Mediator an Firm Size and Industry as Moderators. Investment Management and Financial Innovations. 8(3): 121-129.

Damayanti, I. F. I., Noviansyah, R., \& Muhammad, M. (2018). Pengaruh Kinerja Keuangan Terhadap Nilai Perusahaan Pada Perusahaan Makanan dan Minuman Yang Terdaftar Di Bursa Efek Indonesia Tahun 2014-2016. Jurnal Riset Akuntansi. 1(1): 130-140.

Erlangga. (2009). Pengaruh Kinerja Keuangan Terhadap Nilai Perusahaan Dengan Pengungkapan CSR, Good Corporate Governance Dan Kebijakan Dividen Sebagai Variabel Pemoderasi. Jurnal Akuntansi Dan Investasi. 10(1): 1-25.

Fadhli, M. (2015). Pengaruh Likuiditas, Solvabilitas, dan Profitabilitas terhadap Nilai Perusahaan dengan Kebijakan Dividen sebagai Variabel Moderasi pada Perusahaan Perbankan, Asuransi dan Lembaga Keuangan lainnya di BEI Tahun 2010-2013. Jom FEKON. 2(2): 1-14.

Fahmi, I. (2015). Analisis Kinerja Keuangan. Alfabeta. Bandung.

Fraenkel, J. R., Norman, E.W., \& Helen H.H. (2008). How to Design and Evaluate Research in Education. New York: McGraw-Hill.
Ghozali, I. (2013). Aplikasi Analisis Multivariate Dengan Program SPSS. Badan Penerbit Universitas Diponegoro, Semarang.

Gujarati, D. (2007). Dasar-dasar Ekonometrika Jilid I. Erlanggan: Jakarta.

Hanafi, M. M. (2014). Manajemen Keuangan. Edisi Pertama. BPFE : Yogyakarta.

Hanafi, M. M., \& Halim, A. (2009). Analisis Laporan Keuangan. Yogyakarta : Sekolah Tinggi Tinggi Ilmu Manajemen YKPN.

Harahap, S. S. (2015). Analisis Kritis Atas Laporan Keuangan. Edisi 11. Rajawali Pers. Jakarta.

Kasmir. (2016). Analisis Laporan Keuangan. Jakarta : PT Raja Grafindo Persada.

Kurniasari, M. P., \& Wahyuati, A. (2017). Pengaruh Profitabilitas, Rasio Aktivitas dan Leverage Terhadap Nilai Perusahaan Manufaktur Di BEI. Jurnal Ilmu Dan Riset Manajemen. 6(8): 2-19.

Kushartono, R. C., \& Nurhasanah, N. (2017). Analisis Pengaruh Rasio Keuangan Terhadap Nilai Perusahaan Yang Tergabung Dalam Indeks LQ45 Periode 2010-2016. Buana Ilmu. 108-125.

Lestari. (2017). Pengaruh Likuiditas, Leverage, Dan Profitabilitas Terhadap Nilai Perusahaan Dengan Kebijakan Dividen Sebagai Variabel Moderating. E-Jurnal Manajemen. 1-15.

Mahendra, A., Artini, L. G. S., \& Suarjaya, A. G. (2012). Pengaruh Kinerja Keuangan Terhadap Nilai Perusahaan Pada Perusahaan Manufaktur Di Bursa Efek Indonesia. Jurnal Manajemen, Strategi Bisnis Dan Kewirausahaan. 6(2): 130-138.

Martani, D., Khairurizka, R., \& Khairurizka, R. J. C. B. R. (2009). The Effect of Financial Ratios, Firm Size, and Cash Flow From Operating Activities In The Interim Report to The Stock Return. Chinese Business Review. 8.(6): 44-55. 
Martini, P., \& Rihadjo, I. B. (2014). Pengaruh Kebijakan Utang Dan Profitabilitas Terhadap Nilai Perusahaan: Kebijakan Dividen Sebagai Variabel Pemoderasi. Jurnal Ilmu dan Riset Akuntansi. 3(2).

Mabruroh, V., Riswan, R., \& Lestari, S. (2015). Pengaruh Price Earning Ratio, Leverage, Dividend Payout Ratio, Profitabilitas Dan Cash Holdings Terhadap Nilai Perusahaan Pada Perusahaan NonKeuangan Yang Terdaftar Dalam Indeks Lq45. Monex. 4(1): 82-90.

Mery, K. N. (2017). Pengaruh Likuiditas, Leverage dan Profitabilitas Terhadap Nilai Perusahaan Dengan Kebijakan Dividen Sebagai Variabel Moderasi Pada Perusahaan Pertambangan Yang Terdaftar Di Bursa Efek Indonesia Tahun 2011-2014. JOM Fekon 4(1): 2000-2014.

Murhadi, W. R. (2013). Analisis Laporan Keuangan, Proyeksi dan Valuasi Saham. Jakarta: Salemba Empat.

Munawir, S. (2010). Analisa Laporan Keuangan. Yogyakarta: Liberty.

Nugroho, W. A. (2012). Pengaruh Profitabilitas, Likuiditas, dan Leverage Terhadap Nilai Perusahaan (Studi Pada Perusahaan Sektor Manufaktur Di BEI Periode 2008-2011). Thesis. Universitas Muhammadiyah Surakarta.

Periansya. (2015). Analisis Laporan Keuangan. Palembang: Politeknik Negeri Sriwijaya.

Prasetyorini, B. F. (2013). Pengaruh Ukuran Perusahaan, Leverage, Price Earning Ratio dan Profitabilitas terhadap Nilai Perusahaan. Jurnal Ilmu Manajemen. 1(1): 183-196.

Reeve, J. M., Warren, C. S., \& Duchac, J. E. (2010). Pengantar Akuntansi Adaptasi Indonesia. Jakarta: Salemba Empat.
Rinnaya, I. Y., Andini, R., \& Oemar, A. (2016). Pengaruh Profitabilitas, Rasio Aktivitas, Keputusan Pendanaan dan Keputusan Investasi Terhadap Nilai Perusahaan. Journal Of Accounting. 2(2): 118.

Riyanto, B. (2010). Dasar-dasar Pembelanjaan Perusahaan. Yogyakarta: BPFE.

Sartono, A. (2010). Manajemen Keuangan Teori dan Aplikasi. Edisi Keempat. Yogyakarta: BPFE.

Sianturi, M. W. (2015). Pengaruh Kinerja Keuangan Terhadap Nilai Perusahaan Manufaktur Sektor Industri Barang Konsumsi Di BEI. E-Jurnal Ilmu Administrasi Bisnis. 3(2): 282-296.

Sudana, I. M. (2011). Manajemen Keuangan Perusahaan. Jakarta : Erlangga.

Sukoco, H. (2013). Analisis Pengaruh Debt to Equity Ratio, Profitabilitas, Firm Size, dan Likuiditas Terhadap Nilai Perusahaan Melalui Mediasi Divident Payout Ratio (Studi Pada Industri Manufaktur Di Bursa Efek Indonesia Periode Tahun 2009-2011). Jurnal Bisnis Strategi. 22(2): 112-127.

Sundari, T. W., \& Utami, W. (2013). Pengaruh Kinerja Keuangan terhadap Nilai Perusahaan dengan Kebijakan Dividen. Jurnal MIX. 3(3): 309-321.

Sutama, D. R., \& Lisa, E. (2018). Pengaruh Leverage dan Profitabilitas Terhadap Nilai Perusahaan (Studi pada Perusahaan Sektor Manufaktur Food and Beverage yang Terdaftar di Bursa Efek Indonesia). Jurnal Sains Manajemen \& Akuntansi. 10(1): 2139.

Taslim, F. A. (2016). Pengaruh Rasio Likuiditas, Aktivitas Dan Profitabilitas Terhadap Nilai Perusahaan Dengan Kebijakan Dividen Sebagai Variabel Intervening. Equilibrium Journal. 10(1): 129. 